\title{
The Interaction of Heparin with an Apoprotein of Human Very Low Density Lipoprotein
}

\author{
Frank A. Shelburne and Steven H. Quarfordt, Cooperative Lipid Laboratory, \\ Durham Veterans Administration Hospital, Durham 27705, and Department of \\ Medicine, Duke University Medical Center, Durham, North Carolina 27710
}

A B S T R A C T An arginine-rich apoprotein obtained from human triglyceride-rich lipoprotein was isolated on a heparin affinity column when either the aqueousor urea-soluble apoproteins were applied to the column. Of all the aqueous- or urea-soluble apoproteins, only this arginine-rich protein exhibited a binding affinity to heparin. This protein was eluted from the column at sodium chloride concentrations above $0.35 \mathrm{M}$ in the absence of urea and between 0.17-0.2 $\mathrm{M}$ when isolated in urea. The protein has been characterized by amino acid analysis, immunoelectrophoresis, dodecyl sulfate polyacrylamide electrophoresis, isoelectric focusing, and $\mathrm{NH}_{2}$-terminal analysis. It has the same amino acid composition, $\mathrm{NH}_{2}$-terminal, and molecular weight as previously described for human argininerich apoprotein.

The triglyceride-rich lipoproteins of fasting normal humans were eluted as two fractions when applied to the heparin affinity column. A small amount was eluted in the unbound fraction and this species contained virtually no arginine-rich apoprotein. The bulk of the triglyceride-rich lipoproteins eluted in the bound fraction and contained appreciable amounts of argininerich apoprotein. The bound lipoproteins had more cholesterol and cholesterol ester and less triglyceride than the unbound. The isolated arginine-rich apoprotein was derivatized with phenylglyoxal with a resulting alteration of $75 \%$ of the arginine residues. This modified apoprotein did not bind to the heparin affinity column. Similar treatment of the whole triglyceriderich lipoprotein produced a lipoprotein that was totally eluted in the unbound fraction.

\section{INTRODUCTION}

An arginine-rich apoprotein (ARP) ${ }^{1}$ initially described by Shore and Shore (1) in human very low density lipo-

This work was presented in part at the Southern Society for Clinical Investigation, January 1975.

Received for publication 20 December 1976 and in revised form 13 June 1977.

${ }^{1}$ Abbreviations used in this paper: ARP, arginine-rich apoprotein; SDS, sodium dodecyl sulphate; VLDL, very low density lipoprotein. protein (VLDL) was purified for chemical characterization using guanidine-Sepharose chromatography (2). The molecular size and some of the chemistry of the apoprotein was determined, but because of the complete insolubility of the apoprotein when guanidine was removed, investigations of its function were limited. Although in humans this apoprotein is predominantly associated with the triglyceride-rich lipoproteins, no role for it in plasma-triglyceride metabolism has been described. It has been noted that the apoprotein occurs in VLDL with high contents of cholesterol ester (3), leading to the suggestion that it is related to plasma sterol ester transport. Studies of lecithincholesterol acyltransferase-deficient patients $(4,5)$ have demonstrated increments of ARP in triglyceriderich lipoproteins when active lecithin-cholesterol acyltransferase is added to the system, supporting a role for the apoprotein in plasma cholesterol ester metabolism.

The present study reports the observation that the ARP either free in solution, or on triglyceride-rich lipoproteins, binds to heparin and can be isolated on a heparin affinity column. The binding occurs in the absence of divalent cations. This binding also permits the separation of the bulk of triglyceride-rich lipoproteins which contain ARP and bind to heparin from a small amount of triglyceride-rich lipoprotein in the plasma which contains virtually no ARP and are eluted in the unbound fraction. Derivatization of the apoprotein suggests that the arginine residues on this apoprotein have an important role in heparin binding.

\section{METHODS}

\begin{abstract}
Apoprotein preparation. Blood was collected from normal humans and patients with elevated plasma VLDL concentrations (type IV phenotype) in disodium EDTA $(1 \mathrm{mg} / \mathrm{ml})$. All subjects were sampled after a 14 -h fast. The plasma was separated from the erythrocytes by centrifugation at 2,500 rpm for $20 \mathrm{~min}$ in a Sorvall model RC 2-B refrigerated centrifuge (Du Pont Co., Instrument Products Div., Wilmington, Del.) at $8^{\circ} \mathrm{C}$. Lipoproteins were isolated by a modification of the method described by Havel et al. (6). Chylomicrons were removed from the plasma of each subject by ultracentrifugation at the native plasma density for $25 \mathrm{~min}$ at $20,000 \mathrm{rpm}$ $\left(1 \times 10^{6} \mathrm{~g}\right.$-min $)$ in a Spinco model L-2 centrifuge using a 40-rotor (Beckman Instruments, Inc., Spinco Div., Palo Alto,
\end{abstract}


Calif.). VLDL $\left(S_{f} 20-400\right)$ were isolated from the chylomicronfree plasma by ultracentrifugation at $40,000 \mathrm{rpm}$ for $18 \mathrm{~h}$ $\left(1 \times 10^{8} \mathrm{~g}\right.$-min) at density 1.006 at $8^{\circ} \mathrm{C}$. VLDL were floated through saline twice by a similar ultracentrifugation and were dialyzed against $200 \mathrm{vol}$ of $0.01 \%$ EDTA buffered to $\mathrm{pH} 7.4$ before delipidation. The VLDL were delipidated at $4^{\circ} \mathrm{C}$ by three extractions with ethanol-diethyl ether $(3: 1)$ using $50 \mathrm{vol}$ of solvent per volume of lipoprotein. The resulting apoprotein contained $<0.2 \%$ lipid as phospholipid.

Affinity chromatography. A heparin affinity column was prepared by covalently linking heparin to cyanogen bromideactivated Sepharose $4 \mathrm{~B}$ and subsequently reacting the mixture with ethanolamine exactly as described by Kato and Anfinsen (7) and Iverius (8). [ $\left.{ }^{35} \mathrm{~S}\right] \mathrm{Heparin}$ (The Radiochemical Centre, Amersham, England) was included in some of the preparations to determine the amount of heparin bound to the gel. Other chemicals and radiochemicals were obtained from commercial sources. A mean of $0.4-0.5 \mathrm{mg}$ heparin $/ \mathrm{ml}$ wet gel was observed in these preparations. The column was made to a height of $12 \mathrm{~cm}$ with a diameter of $2.5 \mathrm{~cm}$, and equilibrated with $100 \mathrm{ml}$ of $0.12 \mathrm{M} \mathrm{NaCl}, 2 \mathrm{mM}$ sodium phosphate, pH 7.4. The apoproteins previously prepared were extracted several times with $5-\mathrm{ml}$ aliquots of $0.12 \mathrm{M} \mathrm{NaCl}, 2 \mathrm{mM}$ phosphate, $\mathrm{pH} 7.4$, to an apoprotein concentration of $0.5-2.5$ $\mathrm{mg} / \mathrm{ml}$. The buffer-soluble apoproteins, in a $20-30$ - $\mathrm{ml}$ volume, were applied to the affinity column at a rate of $\cong 30 \mathrm{ml} / \mathrm{h}$. The column was eluted at a similar rate with $400 \mathrm{ml}$ of a linear salt

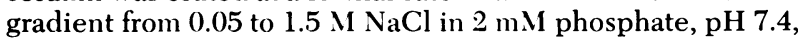
and the eluates were monitored at $280 \mathrm{~nm}$.

After the buffer-soluble apoproteins were obtained, the insoluble residue was reextracted with $5 \mathrm{M}$ urea $2 \mathrm{mM}$ sodium phosphate ( $\mathrm{pH} 7.4$ ) $0.05 \mathrm{M} \mathrm{NaCl}$ buffer. The urea-soluble apoproteins were applied to the heparin affinity column that had been equilibrated with the urea buffer and then run in a $0.05-0.5 \mathrm{M} \mathrm{NaCl}$ gradient in the urea phosphate system. The urea-insoluble residue was lyophilized and dissolved in the soidum dodecyl sulfate (SDS) buffer for subsequent electrophoresis to estimate the amount of insoluble ARP. Native whole VLDL were also applied to the column at protein concentrations of $0.5-1.0 \mathrm{mg} / \mathrm{ml}$ in $10-30 \mathrm{ml}$ and run under the same conditions as the buffer-soluble apoproteins. The mean recovery of protein from the column was $>90 \%$ for both whole lipoproteins and apoproteins.

Polyacrylamide electrophoresis. The procedure used was that of Weber and Osborn (9). Gels of $10 \%$ acrylamide were prepared in a $0.1 \mathrm{M}$ phosphate buffer, pH 7.0, and $0.2 \%$ SDS. Samples of $\cong 45 \mu \mathrm{g}$ of protein were mixed with one drop of glycerol, $5 \mu \mathrm{l}$ of mercaptoethanol, $50 \mu \mathrm{l}$ of buffer, and $3 \mu \mathrm{l}$ of tracking dye. The samples, along with protein standards of known molecular weight, were applied to the gel and subjected to electrophoresis at $360 \mathrm{~V}$ for $2-5 \mathrm{~h}$ in $0.05 \mathrm{M}$ phosphate $(0.1 \%$ SDS) buffer, $\mathrm{pH} 7.0$. The gels were stained with either Coomassie Blue or amido-Schwartz and were destained with a solution containing $7.5 \%$ acetic acid and $5 \%$ methanol in water at $60^{\circ} \mathrm{C}$ with changes of solution every halfhour until completion. The gels were scanned using a Gilford gel scanner (Gilford Instruments Laboratories Inc., Oberlin, Ohio) and the responses integrated by planimetry. Isoelectric focus was run in a Multiphor apparatus (LKB Instruments, Inc., Rockville, Md.) using Ampholines (LKB-Produkter, Bromma, Sweden) in either the $\mathrm{pH} 3-10$ or 4-6 range according to an established method (10).

Amino acid analysis. The analyses were carried out according to the procedure of Spackman et al. (11) on a Beckman model 121 analyzer (Beckman Instruments Inc., Fullerton, Calif.). Protein samples dialyzed free of $\mathrm{NaCl}$ were routinely hydrolyzed for $24 \mathrm{~h}$ with oxygen-free $6 \mathrm{~N} \mathrm{HCl}$ at $108^{\circ} \mathrm{C}$ in a nitrogen atmosphere. Hydrolysates were dried in a vacuum dessicator over sodium hydroxide, dissolved in $0.005 \mathrm{~N} \mathrm{HCl}$, and applied to the analyzer column. $\mathrm{NH}_{2}$-terminal analysis was performed on the heparin affinity isolated apoprotein by the dansyl method exactly as previously described (2).

Protein analysis and modification. Protein determinations were performed according to the method of Lowry et al. (12) using bovine albumin as a standard. Both the isolated apoprotein from the affinity column and native VLDL were derivatized with phenylglyoxal exactly as described by Takahashi for bovine RNAse (13). The phenylglyoxal was dialyzed away from the apoprotein or lipoprotein in 1,000 vol of appropriate buffer for subsequent incubation or chromatography. No change in the SDS-polyacrylamide electrophoretic behavior or immunochemical reactivity was noted for the ARP after phenylglyoxal treatment.

Lipoprotein incubations. Freshly prepared VLDL were incubated in a $0.03 \mathrm{M}$ Tris, $\mathrm{pH} 7.4,0.12 \mathrm{M} \mathrm{NaCl}$ buffer at concentrations of $2 \mathrm{mg}$ protein $/ \mathrm{ml}$ and $0.03 \mu \mathrm{Ci}\left[{ }^{35} \mathrm{~S}\right]$ heparin (CalAtomic, Inc., Los Angeles, Calif.) (sp act $0.2 \mu \mathrm{Ci} / \mathrm{mg}$ ). The incubations were performed at $37^{\circ} \mathrm{C}$ for $3 \mathrm{~h}$ in a Dubnoff metabolic shaker. The lipoprotein was isolated by ultracentrifugation and delipidated as previously described. The incubation buffer was added to the apoproteins to obtain a soluble apoprotein concentration of $\cong 10 \mathrm{mg} / \mathrm{ml}$ and this solution containing $\left[{ }^{35} \mathrm{~S}\right]$ heparin was used for immunochemical evaluations. Native and phenylglyoxal-derivatized VLDL at protein concentrations from $1-5 \mathrm{mg} / \mathrm{ml}$ were incubated with $0.03 \mu \mathrm{Ci} / \mathrm{ml}\left[{ }^{35} \mathrm{~S}\right]$ heparin, sp act $0.2 \mu \mathrm{Ci} / \mathrm{mg}$ in a $0.1 \mathrm{MN}$-ethylmorpholine buffer at $\mathrm{pH} 5.5$ for $3 \mathrm{~h}$ at $37^{\circ} \mathrm{C}$. The lipoproteins were isolated by ultracentrifugation and along with the infranate, assayed for radioactivity. The incubation buffer was changed to more acid conditions to stabilize the VLDL derivative (13). No differences were observed for heparin binding to fresh VLDL in this buffer as compared to the tris buffer at higher $\mathrm{pH}$.

Immunodiffusion. Antisera to apoproteins were placed in the center well of a standard immunodiffusion system (14), and the aqueous-soluble apoproteins from VLDL which had been incubated with $\left.{ }^{35} \mathrm{~S}\right]$ heparin and concentrated in a UM-2 Amicon Filter (Amicon Corp., Lexington, Mass.) were placed in peripheral wells. A blank well with the same content of $\left[{ }^{35} \mathrm{~S}\right]$ heparin was included in each immunodiffusion study. After development in a humid chamber of $24-48 \mathrm{~h}$, the immunoprecipitin bands were cut from the gels and placed in counting vials, ground to small particle size with a pestle, and dispersed in $10 \mathrm{ml}$ of Aquasol for radioactivity assay in a Packard model 3375 Liquid Scintillation spectrometer (Packard Instrument Co., Inc., Downers Grove, Ill.). The antisera to the individual $\mathrm{C}$ apolipoproteins ${ }^{2}$ and the ARP were prepared in our laboratory by sequential immunizations of rabbits. Other antisera were obtained from commercial sources.

Lipid analysis. Triglyceride determinations on the lipoprotein fractions were obtained by an automatic fluorometric technique (15). Cholesterol and cholesterol esters were assayed by the Schoenheimer-Sperry method (16). Phospholipid determinations were performed on the extracts by Folch et al. (17) of the lipoproteins by the method of Ames and Dubin (18).

\section{RESULTS}

After ethanol ether delipidation, most of the VLDL apoproteins soluble in phosphate buffer were the previously characterized $C$ apolipoproteins $(19,20)$. A group of uncharacterized apoproteins having molecular

${ }^{2} \mathrm{C}$ apolipoproteins, these include the apo-Ser, apo-Glu, and apo-Ala proteins named according to the carboxy terminus. 


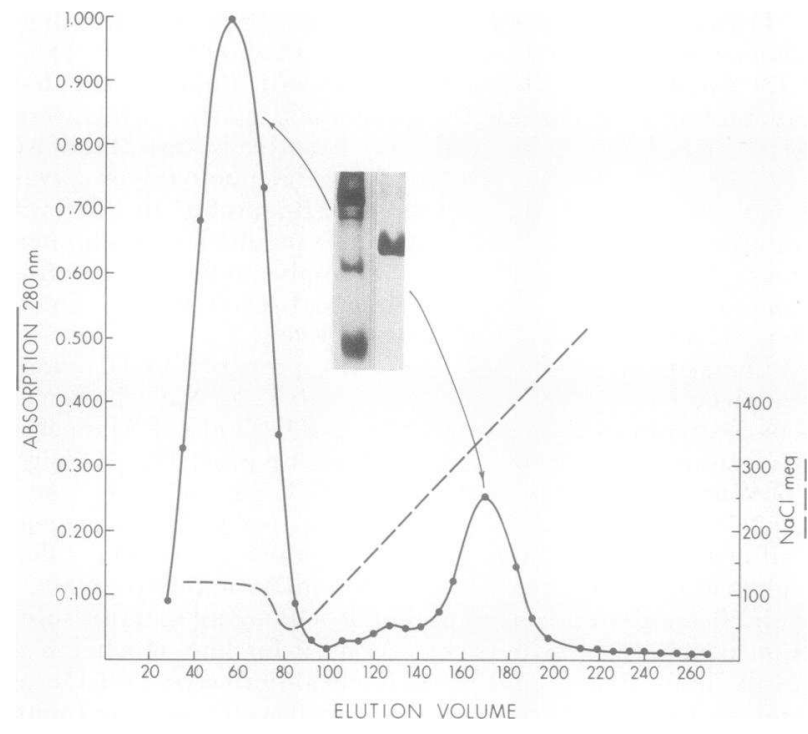

Figure 1 Heparin affinity chromatography of $26 \mathrm{mg}$ of soluble VLDL apoprotein. This was applied to the column in $25 \mathrm{ml}$ of buffered $0.12 \mathrm{M} \mathrm{NaCl}$ solution and eluted with a salt gradient from 0.05 to $1.5 \mathrm{M} \mathrm{NaCl}$. The insets show the results of SDS-polyacrylamide electrophoresis of the separated peaks.

weights from 50,000 to 90,000 daltons were also buffer soluble. A small amount of ARP was detected in the soluble fraction by both SDS-polyacrylamide electrophoresis and immunoelectrophoresis. When the buffersoluble apoprotein was applied to a heparin affinity column and eluted with a linear salt gradient, two fractions were eluted from the column (Fig. 1). The initial fraction was eluted at $\mathrm{NaCl}$ concentrations below $0.12 \mathrm{M}$ and was found to contain no ARP in over one hundred chromatograms that had been run. A second protein fraction which eluted at $\mathrm{NaCl}$ concentrations from 0.35 to $0.4 \mathrm{M}$ was found to be pure ARP by SDSpolyacrylamide electrophoresis (Fig. 1), immunoelectrophoresis, and $\mathrm{NH}_{2}$-terminal analysis. The total amount of buffer-soluble ARP recovered and assayed by amino acid analysis was usually $<1.5 \%$ of the mass of the delipidated apoproteins.

The buffer-soluble ARP recovered from the affinity column had a similar amino acid content (Table I) to the ARP previously described (21-24) and was immunochemically identical with the ARP purified by guanidine-Sepharose chromatography (2). The pure affinity-isolated ARP was run on a Multiphor Isoelectric Focus Unit (LKB Instrument, Inc.) in the pH 3-10 and 4-6 range, and it demonstrated at least five components with $\mathrm{pI}$ ranging from 5.8 to $6.3 . \mathrm{NH}_{2}$-terminal analysis of the affinity-isolated ARP by the dansyl procedure with guanidine-Sephadex chromatography before hydrolysis (2) indicated lysine as the $\mathrm{NH}_{2}$-terminal residue as was previously noted for the guanidineprepared apoprotein (2).

\section{F. A. Shelburne and S. H. Quarfordt}

TABLE I

Amino Acid Analysis of Affinity-Isolated Apoprotein

\begin{tabular}{lcccc}
\hline \multicolumn{1}{c}{ Amino acids } & $\begin{array}{c}\text { Published } \\
\text { range* }\end{array}$ & $\begin{array}{c}\text { Buffer-soluble } \\
\text { affinity ARPt }\end{array}$ & $\begin{array}{c}\text { Phenyl glyoxal } \\
\text { ARP§ }\end{array}$ & $\begin{array}{c}\text { Urea-soluble } \\
\text { affinity ARPt }\end{array}$ \\
\hline \multicolumn{4}{c}{ mol/103 mol } \\
Lysine & $46-55$ & 48.4 & 56.2 & 49.5 \\
Histidine & $11-13$ & 12.9 & 10.9 & 9.6 \\
Arginine & $93-109$ & 106.8 & 25.1 & 116.0 \\
Aspartic acid & $47-57$ & 54.5 & 53.8 & 47.5 \\
Threonine & $37-51$ & 44.4 & 41.5 & 41.0 \\
Serine & $51-76$ & 56.7 & 53.8 & 59.2 \\
Glutamic acid & $228-238$ & 235.2 & 249.5 & 226.4 \\
Proline & $21-37$ & 37.6 & 41.6 & 32.0 \\
Glycine & $58-68$ & 56.4 & 68.0 & 65.0 \\
Alanine & $92-118$ & 111.9 & 121.0 & 94.9 \\
Cysteine & 0 & 0 & 0 & 0 \\
Valine & $59-70$ & 70.9 & 71.8 & 60.4 \\
Methionine & $11-25$ & 19.7 & 25.2 & 21.4 \\
Isoleucine & $6-13$ & 10.6 & 9.6 & 11.7 \\
Leucine & $105-125$ & 118.2 & 133.0 & 111.2 \\
Tyrosine & $14-17$ & 18.4 & 16.2 & 17.5 \\
Phenylalanine & $14-19$ & 15.7 & 19.0 & 19.6 \\
\hline
\end{tabular}

* Obtained from the following sources: references 21-24.

$\ddagger$ Average of determinations from two normal subjects.

$\$$ Average of two determinations of a derivative of the buffersoluble apoprotein isolated by affinity chromatography.

An appreciable amount of the aqueous buffer-insoluble residue went into solution when it was reextracted with a similar buffer containing $5 \mathrm{M}$ urea. When the urea-soluble fraction was applied to the heparin affinity column using the same $\mathrm{NaCl}$ gradient as previously, two major peaks were again observed. The second peak which eluted at $\mathrm{NaCl}$ concentrations from 0.17 to $0.20 \mathrm{M}$ was found to contain only ARP (Fig. 2). A better separation of the peaks could be produced if a more shallow $\mathrm{NaCl}$ gradient (i.e. $0.05-0.5 \mathrm{M}$ ) were used (Fig. 4). The urea-soluble ARP recovered from the heparin affinity column usually accounted for $6.5-8.5 \%$

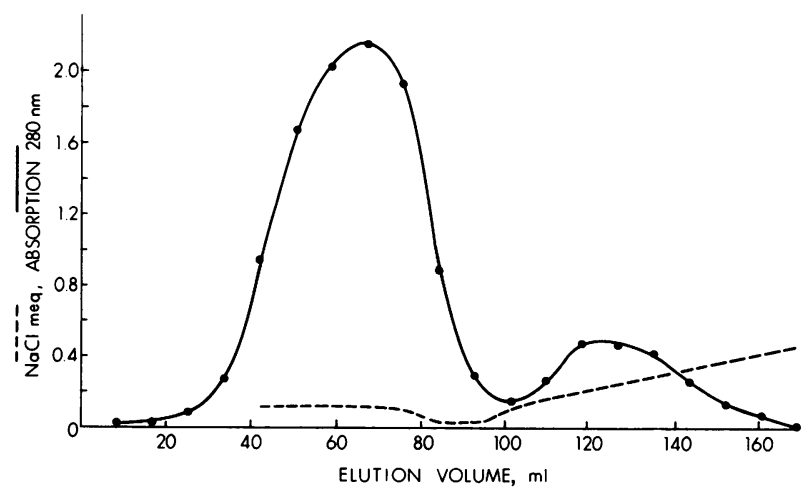

FIGURE 2 Heparin affinity chromatography of VLDL apoproteins soluble in $5 \mathrm{M}$ urea, $0.12 \mathrm{M} \mathrm{NaCl}$, and $2 \mathrm{mM}$ phosphate. The gradient was the same as in Fig. 1 . 
of the delipidated apolipoproteins when assayed by amino acid analysis. The current estimates of total VLDL-ARP from VLDL prepared ultracentrifugally may be spuriously low because of ultracentrifugal losses. At present, it is impossible to relate the recovery of the ARP obtained from the affinity chromatography of these studies to the total ARP on VLDL prepared by gel filtration since this information is currently unavailable. The urea-soluble affinity-isolated apoprotein had a similar amino acid composition (Table I) and the same $\mathrm{NH}_{2}$-terminal (lysine), molecular size, and immunochemical behavior as the buffer-soluble ARP. The residue after the urea buffer extraction was predominantly the apo beta protein but usually had traces of the ARP.

When native VLDL from fasting normal and hyperlipoproteinemic (type IV phenocopy) patients was applied to the affinity column, two distinct fractions of VLDL were eluted (Fig. 3). A small amount of lipoprotein equivalent to no more than one-fourth of total lipoprotein came off the column at $\mathrm{NaCl}$ concentrations below $0.12 \mathrm{M}$ with the bulk of the lipoprotein eluted between 0.2 and $0.25 \mathrm{M}$. The unbound VLDL fraction contained the apo beta protein, the $\mathrm{C}$ apolipoproteins and variable quantities of larger (50-90,000 daltons) uncharacterized apoproteins by SDS-polyacrylamide electrophoresis and immunoelectrophoresis but only a trace of ARP (Fig. 3). The bound fraction had the apo beta and $\mathrm{C}$ apolipoproteins and the ARP was a prominent component. Both the bound and unbound lipoproteins rechromatographed in the same elution volumes where they were isolated. These two lipoprotein fractions also differed in their lipid contents (Table II), the bound fraction containing relatively more sterol ester and cholesterol and less triglyceride than the unbound.

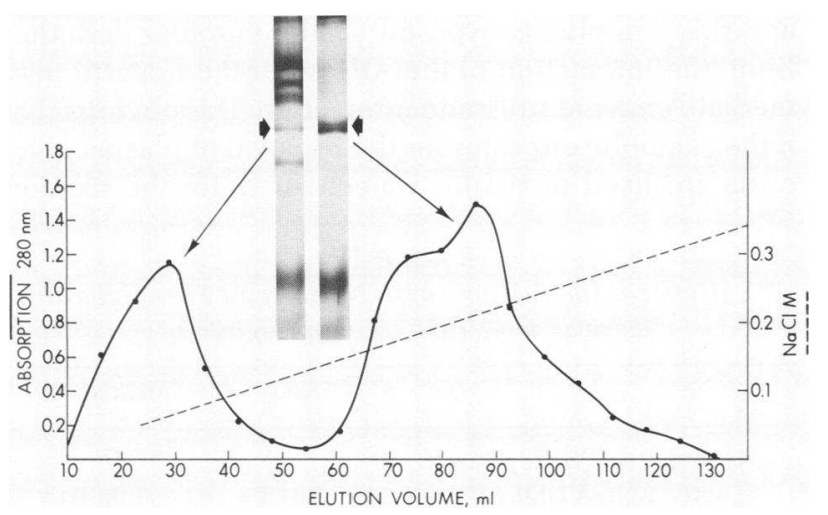

FIGURE 3 Heparin affinity chromatography of whole VLDL ( $9.5 \mathrm{mg}$ protein) applied in $25 \mathrm{ml}$ using the same conditions as in Fig. 1. The insets also show results of SDS-polyacrylamide electrophoresis of separated peaks after delipidation. The arrows at the side of each inset give the migration of standard ARP.
TABLE II

Relative Lipid Composition of Heparin Bound and Unbound Whole VLDL Fractions

\begin{tabular}{lcccc}
\hline & Phospholipid & $\begin{array}{c}\text { Free } \\
\text { cholesterol }\end{array}$ & $\begin{array}{c}\text { Cholesterol } \\
\text { ester }\end{array}$ & Triglyceride \\
\hline & & $\%$ of total lipid* & \\
Normals & & & & \\
$\quad$ Unbound & $19.2(1.8)$ & $4.6(.3)$ & $4.2(.1)$ & $72.8(1.7)$ \\
$\quad \begin{array}{c}\text { Bound } \\
\text { Hyperlipoprotein- }\end{array}$ & $21.4(.9)$ & $7.6(.2)$ & $9.8(.4)$ & $61.8(2.1)$ \\
$\begin{array}{c}\text { emia (Type IV) } \\
\text { Unbound }\end{array}$ & $21.1(2.1)$ & $5.2(.2)$ & $4.9(.1)$ & $70.4(1.9)$ \\
$\quad$ Bound & $19.6(1.6)$ & $7.5(1)$. & $12.2(.3)$ & $61.2(1.1)$ \\
\hline
\end{tabular}

* These values represent the mean values of five individuals in each category. The bound and unbound lipoprotein cholesterol, cholesterol ester, and triglyceride values are significantly different at $P<0.01$, by Student's $t$ test.

Urea-soluble ARP isolated from the heparin affinity column was reapplied to the same column immediately after isolation (Fig. 4). The rechromatographed apoprotein was eluted in about the same elution volumes it was originally isolated. An aliquot of this apoprotein was derivatized with phenylglyoxal which produced an alteration of $\cong 75 \%$ of the arginine residues (Table I) and reapplied to the same column. The derivatized protein was totally eluted in the unbound fraction (Fig. 4) with an extinction coefficient of the derivative greater than the parent protein. When native VLDL was similarly derivatized and reapplied to the column, all the lipoprotein eluted in the unbound fraction (Fig. 5) with no trace of bound lipoprotein as was previously noted for the native VLDL (Fig. 3).

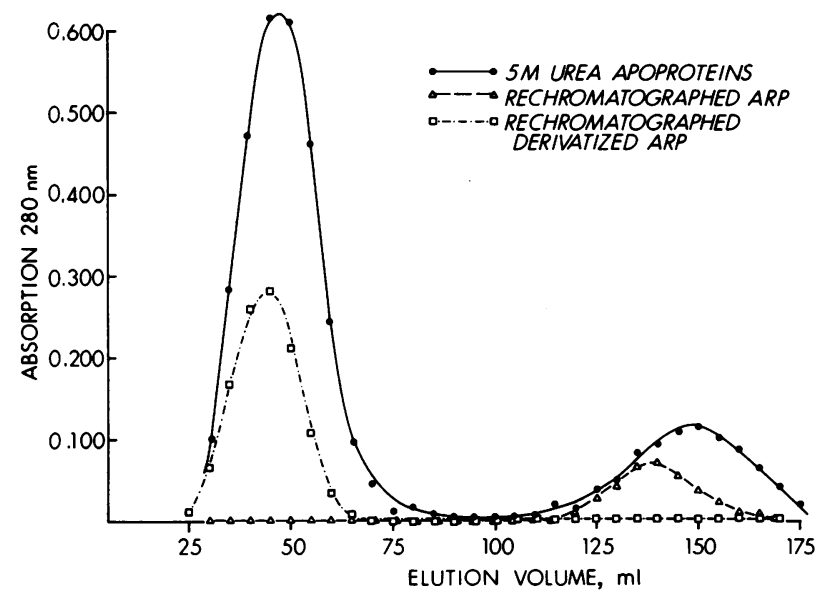

Figure 4 The VLDL apoproteins soluble in $5 \mathrm{M}$ urea, $0.12 \mathrm{M} \mathrm{NaCl}$, and $2 \mathrm{mM}$ phosphate chromatographed on a heparin affinity column (O) one-half of the second peak (i.e. ARP) rechromatographed on the same column $(\Delta)$. The other half of the affinity isolated ARP derivatized with phenylglyoxal and reapplied to the same column ( $\square$ ). 


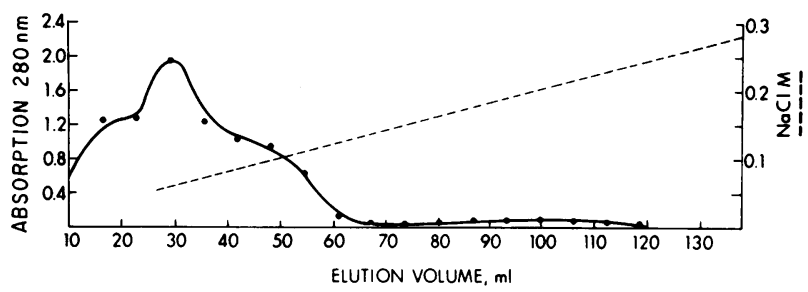

FIGURE 5 Heparin affinity chromatography of phenylglyoxalderivatized whole VLDL ( $7.0 \mathrm{mg}$ protein). The conditions are the same as in Fig. 2.

Dialyzed freshly prepared native VLDL (2 mg protein $/ \mathrm{ml}$ ) was incubated in 0.03 Tris, $\mathrm{pH} 7.5,0.12 \mathrm{M}$ $\mathrm{NaCl}$ buffer containing $0.03 \mu \mathrm{Ci} / \mathrm{ml}$ of $\left[{ }^{35} \mathrm{~S}\right]$ heparin (sp act $0.2 \mu \mathrm{Ci} / \mathrm{mg}$ ). The incubations were performed at $37^{\circ} \mathrm{C}$ for $3 \mathrm{~h}$ in a Dubnoff metabolic shaker after which the VLDL was isolated by ultracentrifugation and delipidated as described. The aqueous-soluble apoproteins were concentrated to $8.6 \mathrm{mg}$ protein and $0.14 \mu \mathrm{Ci}\left[{ }^{35} \mathrm{~S}\right]$ heparin $/ \mathrm{ml}$ by ultrafiltration on a UM-2 filter and evaluted by immunodiffusion using antisera to the apo-Ser, apo-Ala, apo-Glu, ARP prepared in rabbits by sequential immunization and commercially obtained antisera to high density lipoprotein. Although most of the protein in the aqueous-soluble apoproteins was the apo-Ala, apo-Glu, and apo-Ser apoproteins, the largest recovered heparin activities were in the precipitin lines obtained with the antisera to the ARP (Table III).

Native VLDL and phenylglyoxal derivatized VLDL at protein concentrations from 1 to $5 \mathrm{mg} / \mathrm{ml}$ were simi-

TABLE III

$\left.{ }^{35} \mathrm{~S}\right]$ Heparin Activity in Immunoprecipitin Bands of Aqueous-Soluble Apo-VLDL*

\begin{tabular}{lcc}
\hline \multicolumn{1}{c}{ Antisera } & & \\
\hline & $c p m$ & $\%$ \\
Anti-apo-Ser & 189 & 10.1 \\
Anti-apo-Ala & 200 & 10.7 \\
Anti-apo-Glu & 215 & 11.5 \\
Anti-apo-HDL & 175 & 9.3 \\
Anti-apo-Arg (1) & 517 & 27.7 \\
Anti-apo-Arg (2) & 841 & 45.1 \\
Anti-apo-Arg (3) & 743 & 40.2 \\
Anti-heparin blank & 166 & 8.9 \\
\hline
\end{tabular}

* Immunodiffusion technique described in text using antisera to VLDL " $C$ " apoproteins named according to the carboxy terminus. The anti Apo-Arg 1, 2, and 3 are three different lots of antisera to the ARP. The protein concentration of this aqueous-soluble apoprotein was $8.6 \mathrm{mg} / \mathrm{ml}$ with $0.14 \mu \mathrm{Ci} / \mathrm{ml}$ of $\left[{ }^{35} \mathrm{~S}\right]$ heparin. $1 \mu \mathrm{l}$ of solution was applied to each of six antigen wells. Densitometry on the Coomassie Blue-stained apoproteins indicated the following apoprotein percentage: apo-Ser $14 \%$, combined apo-Ala and apo-Glu $68 \%$, apo-Arg $1.5 \%$. larly incubated with $0.03 \mu \mathrm{Ci}\left[{ }^{35} \mathrm{~S}\right]$ heparin $/ \mathrm{ml}$ at $37^{\circ} \mathrm{C}$ for $3 \mathrm{~h}$ in a Dubnoff metabolic shaker using a buffer of $0.1 \mathrm{M} \mathrm{N}$-ethylmorpholine at $\mathrm{pH} 5.5$ to insure stability of the derivative (13). The lipoproteins were subsequently isolated by ultracentrifugation and the activities in the VLDL and the infranatant were assayed. The fresh native VLDL bound a mean of $89 \%$ of the radioactivity at these concentrations, whereas the phenylglyoxal-derivatized lipoprotein bound $30 \%$ of the heparin activity (Table IV). No differences in triglyceride recovery were found after centrifugation for the derivatized and native VLDL.

\section{DISCUSSION}

The triglyceride-rich lipoproteins of humans have a higher content of the ARP than any of the other plasma lipoproteins (2). This is not true for the rat which has much of its ARP in high density lipoproteins (25). Although the human triglyceride-rich lipoproteins carry most of this apoprotein, the functional role of the apoprotein in the metabolism of plasma triglyceride is completely unknown. The observation that the apoprotein is in particularly high concentrations in the triglyceride-rich lipoproteins which have appreciable contents of cholesterol ester $(3,23)$ has led to the postulate that this apoprotein has a role in the plasma transport of cholesterol. The increment of the apoprotein in the triglyceride-rich lipoproteins of humans after lecithin-cholesterol acyltransferase-deficient plasma has been exposed to an active lecithin-cholesterol acyltransferase system $(4,5)$ further supports a role for this apoprotein in plasma sterol metabolism.

The observation that the ARP binds heparin suggests a function for the apoprotein in the catabolism of plasma triglyceride. If heparin or another sulfated glycosaminoglycan is an integral part of the tissue lipoprotein lipase complex, as has been suggested (26), and this complex is exposed on the vascular endothelium, the interaction of the ARP with the heparin may mediate enzyme substrate interaction. It is obvious that if the catabolic enzymes for the removal of plasma glyceride are fixed in tissue, a mechanism for the fixation

TABLE IV

[ $\left.{ }^{35} \mathrm{~S}\right]$ Heparin Incubations with Native and PhenylglyoxalDerivatized VLDL (5 mg protein $/ \mathrm{ml}$ )*

\begin{tabular}{lcc}
\hline & Native & Derivatized \\
\hline $\begin{array}{c}\text { Recovered [ }{ }^{35} \text { S ]heparin } \\
\text { activity in VLDL, \% } \\
\text { Recovered [ }{ }^{35} \text { S ]heparin } \\
\text { activity in infranatant, \% }\end{array}$ & $89(5)$ & $30(3)$ \\
\hline
\end{tabular}

* Values represent the mean (standard deviation) of five incubations under conditions described in the text. The means for derivatized VLDL are significantly different at $P<0.01$. 
of plasma substrate is essential. Although it appears that lipoprotein lipase and heparin are intimately associated in tissue $(26,27)$, the circulating form of the enzyme (28) may have little affinity for heparin. Even if the tissue enzyme had no heparin affinity, the presence of a sulfated glycosaminoglycan in peripheral tissues would still act to anchor the substrate for subsequent catabolism.

The finding that a small amount of human triglyceride-rich lipoprotein in fasting plasma has almost no ARP on it suggests an analogy with the observations in our laboratory, ${ }^{3}$ that chylomicrons of the rat lymph contained little ARP until they were exposed to the plasma. The same situation may be also true for the chylomicrons of humans, although the lipid composition of the unbound fraction is certainly not that of a postabsorptive chylomicron. However, it is recognized that triglyceride-rich lipoproteins are delivered through the lymph even in the fasting situation, and these have more of the characteristics of VLDL (29). The small unbound fraction may thus represent triglyceride-rich lipoproteins newly exposed to plasma that have not yet incorporated the ARP. We have observed that when this unbound fraction is reincubated in plasma, it now binds to the heparin affinity column and contains the ARP in a fashion analogous to rat lymph chylomicrons. Although evidence would indicate that the bulk of the VLDL in hepatic Golgi already contain the ARP (30), there may in fact be an appreciable fraction of the nascent VLDL that does not have the ARP. The heparin affinity column should prove to be an effective tool in isolating the VLDL fraction which contains the apoprotein from that which does not.

Recent in vitro incubations of fibroblasts with a swine lipoprotein containing the ARP also suggest another receptor function for the protein (31). This lipoprotein apparently has the same effect as the beta lipoprotein on cholesterol fibroblast metabolism (32) but contains no beta protein. It was suggested (31) that the ARP possibly serves the same function as the beta protein in this swine lipoprotein. The recognition that the beta protein fibroblast interaction can be disrupted with heparin (33) and that the ARP may be able to substitute for this function suggests that the receptor for cholesterol entry into the cell may be through sulfated glycosaminoglycan protein interaction.

The data presented only substantiate the fact that among the relatively soluble human VLDL apoproteins, it is solely the ARP which appreciably binds to heparin. In view of the similar binding of the human LDL and VLDL to heparin (34), it is quite probable that the apo beta protein also binds to heparin. The

\footnotetext{
${ }^{3}$ Robinson S. F., and S. H. Quarfordt. 1976. Chylomicron apoprotein alteration after plasma exposure. Manuscript in preparation.
}

insolubility of the apo beta protein in virtually all buffer systems makes the definition of this binding relationship difficult to attain. It is interesting that a small amount of human triglyceride-rich lipoprotein that contains the apo beta protein, but virtually no ARP (Fig. 3), does not bind to the affinity column. This might suggest that for the triglyceride-rich species the ARP is functionally more important in this interaction than is the beta protein.

The fact that heparin ARP binding is disrupted in high salt indicates an ionic interaction. The decrease of the binding in urea suggests that protein conformation importantly determines local charge densities which in turn determine the binding affinity. Iverius (8) has previously demonstrated a lack of VLDL or LDL heparin binding when the lipoprotein were acetylated suggesting an importance for the lysine residues. Our data would indicate that the arginine residues of ARP are also important for this interaction. The decreased heparin binding with arginine derivatizations may occur because of an alteration in protein charge, conformation, or both. The ability to derivatize the VLDL arginine residues by a technique which has little effect on primary amino groups provides more direct evidence that the heparin VLDL interaction is a protein-mediated one.

The ARP isolated by the affinity technique, either in aqueous buffers or in urea, differs somewhat from the chemical characteristics of the protein isolated on a guanidine-Sepharose system (2). The latter protein which had been carboxymethylated (2) was virtually completely insoluble in either an aqueous or urea buffer, whereas the affinity isolated proteins are at least readily soluble in urea. The molecular size, immunochemical reactivity, and $\mathrm{NH}_{2}$-terminal residue was similar for the two preparations, but isoelectric focus of the affinity isolated material indicated a polymorphism in the $\mathrm{pH}$ range of 5.8-6.2, somewhat similar to that described by Utermann (24), whereas the guanidine preparation focused as a single basic band (2). Current preparations of guanidine-prepared ARP, when thoroughly dialyzed to rid them of guanidine, yield no ureasoluble material for isoelectric focus studies. It is possible that the previous basic focus of the guanidine-prepared apoprotein may have been a function of residual guanidine remaining with the protein, or possibly the different isoelectric focus techniques used (2).

\section{ACKNOWLEDGMENTS}

We are indebted to Dr. Ram Jain for his valuable assistance in carbohydrate analysis and to Mrs. Sally Menzel for her technical assistance.

This work was supported in part by Institutional Support from the Veterans Administration, 7226-01, and by a research grant (2 RO1 HL14313-04), National Heart and Lung Institute, National Institutes of Health. 


\section{REFERENCES}

1. Shore, V. G., and B. Shore. 1972. Blood Lipids and Lipoproteins: Quantitation, Composition and Metabolism. John Wiley and Sons, Inc. New York. 789 pp.

2. Shelburne, F. A., and S. H. Quarfordt. 1974. A new apoprotein of human plasma very low density lipoproteins. J. Biol. Chem. 249: 1428-1433.

3. Shore, B., and V. Shore. 1974. An apolipoprotein preferentially enriched in cholesterol ester-rich very low density lipoproteins. Biochem. Biophys. Res. Commun. 58: $1-7$.

4. Glomset, J. A., K. R. Norum, A. V. Nichols, W. C. King, C. P. Mitchell, K. R. Applegate, E. L. Gong, and E. Gjone. 1975. Plasma lipoproteins in familial lecithin:cholesterol acyltransferase deficiency: effects of dietary manipulation. Scand. J. Clin. Lab. Invest. Suppl. 35: 3-30.

5. Norum, K. R., J. A. Glomset, A. V. Nichols, T. Forte, J. A. Albers, W. C. King, C. P. Mitchell, K. R. Applegate, E. L. Gong, V. Cabana, and E. Gjone. 1975. Plasma lipoproteins in familial lecithin: cholesterol acyltransferase deficiency: effects of incubation with lecithin:cholesterol acyltransferase in vitro. Scand.J. Clin. Lab. Invest. Suppl. 35: $31-55$.

6. Havel, R. J., H. A. Eder, and J. H. Bragdon. 1955. The distribution and chemical composition of ultracentrifugally separated lipoproteins in human serum. J. Clin. Invest. 34: 1345-1353.

7. Kato, I., and C. B. Anfinsen. 1969. Purification of synthetic ribonuclease $S$-peptide derivatives by specific complex formation on columns of ribonuclease S-protein bound to agarose. J. Biol. Chem. 244: 5849-5855.

8. Iverius, P. H. 1971. Coupling of glycosaminoglycans to agarose beads (Sepharose 4B). Biochem. J. 124: 677-683.

9. Weber, K., and M. Osborn. 1969. The reliability of molecular weight determinations by dodecyl sulfate-polyacrylamide gel electrophoresis. J. Biol. Chem. 244: 4406-4412.

10. Instruction Manual 1-2117-EO1 for LKB Multiphor 2117. LKB Produkter AB, Bromma, Sweden. 1-29.

11. Spackman, D. H., W. H. Stein, and S. Moore. 1958. Automatic recording apparatus for use in the chromatography of amino acids. Anal. Chem. 30: 1190-1206.

12. Lowry, O. H., N. J. Rosebrough, A. L. Farr, and R. J. Randall. 1951. Protein mesurement with the folin phenol reagent. J. Biol. Chem. 193: 265-275.

13. Takahashi, K. 1968. The reaction of phenylglyoxal with arginine residues in proteins. J. Biol. Chem. 243: 61716179.

14. Grafar, P. 1957. Agar-gel diffusion and immunoelectrophoretic analysis. Ann. N. Y. Acad. Sci. 69: 591

15. Kessler, G., and H. Lederer. 1966. Automation in analytical chemistry. In Technicon Symposia. Mediad, New York. 341 .

16. Schoenheimer, R., and W. M. Sperry. 1934. A micromethod for the determination of free and combined cholesterol. J. Biol. Chem. 106: 745-760.

17. Folch, J., M. Lees, and G. H. Sloan-Stanley. 1957. A simple method for the isolation and purification of total lipides from animal tissues. J. Biol. Chem. 226: 495-509.
18. Ames, B. N., and D. T. Dubin. 1960. The role of polyamines in the neutralization of bacteriophage deoxyribonucleic acid. J. Biol. Chem. 235: 769-775.

19. Brown, W. V., R. I. Levy, and D. S. Frederickson. 1969. Studies of the proteins in human very low density lipoproteins. J. Biol. Chem. 244: 5687-5694.

20. Brown, W. V., R. I. Levy, and D. S. Frederickson. 1970. Further separations of the apoprotein of human plasma very low density lipoprotein. Biochim. Biophys. Acta. 280: 573-575.

21. Shore, V. G., and B. Shore. 1973. Heterogeneity of human plasma very low density lipoproteins. Separation of species differing in protein components. Biochemistry. 12: 502-507.

22. Shore, V. G., B. Shore, and R. G. Hart. 1974. Changes in apolipoproteins and properties of rabbit very low density lipoproteins on induction of cholesteremia. Biochemistry. 13: 1579-1584.

23. Havel, R. J., and J. P. Kane. 1973. Primary dysbetalipoproteinemia: predominance of a specific apoprotein species in triglyceride-rich lipoproteins. Proc. Natl. Acad. Sci. U. S. A. 70: 2015-2019.

24. Utermann, G. 1975. Isolation and partial characterization of an arginine-rich apolipoprotein from human plamsa very low density lipoproteins: apolipoprotein E. HoppeSeyler's Z. Physiol. Chem. 356: 113-121.

25. Swaney, J. B., H. Reese, and H. A. Eder. 1974. Polypeptide composition of rat high density lipoprotein; characterization by SDS gel electrophoresis. Biochem. Biophys. Res. Commun. 59: 513-519.

26. Korn, E. D. 1959. Assay of lipoprotein lipase in vivo and in vitro. Methods Biochem. Anal. 7: 145-192.

27. Robinson, D. S. 1963. The clearing factor lipase and its action in the transport of fatty acids between the blood and the tissues. Adv. Lipid Res. 1: 133-181.

28. Fielding, P. E., V. G. Shore, and C. I. Fielding. 1974. Lipoprotein lipase: properties of the enzyme isolated from post-heparin plasma. Biochemistry. 13: 4318-4323.

29. Ockner, R. K., F. B. Hughes, and K. J. Isselbacher. 1969. Very low density lipoproteins in intestinal lymph: origin, composition, and role in lipid transport in the fasting state. J. Clin. Invest. 48: 2079-2088.

30. Marsh, J. B. 1976. Apoproteins of the lipoproteins in a non-recirculating perfusate of rat liver. J. Lipid Res. 17: 85-90.

31. Bersot, T. P., R. W. Mahley, M. S. Brown, and J. L. Goldstein. 1976. Interaction of swine lipoproteins with the low density lipoprotein receptor in human fibroblasts. J. Biol. Chem. 251: 2395-2398.

32. Brown, M. S., and J. L. Goldstein. 1976. Receptor mediated control of cholesterol metabolism. Science (Wash. D. C.). 191: 150-154

33. Goldstein, J. L., S. K. Basu, G. Y. Brunschede, and M. S. Brown. 1976. Release of low density lipoprotein from its cell surface receptor by sulfated glycosaminoglycans. Cell. 7: 85-95.

34. Iverius, P. 1972. The interaction between human plasma lipoproteins and connective tissue glycosaminoglycans. J. Biol. Chem. 247: 2607-2613. 